\title{
Finansal Gelişmişliğin Özel Sektör Ar-Ge Harcamalarına Etkisi: Türkiye İçin Eşbütünleşme, Nedensellik, Etki-Tepki Analizleri Ve Varyans Ayrıştırması (1990-2014)
}

\author{
N. Savaş DEMİRCI *
}

\section{$\ddot{O Z Z E T}$}

Küresel piyasalardaki yoğun rekabet özel sektör işletmelerini AR-GE yatırtmlarına daha fazla kaynak ayırmaya zorlamaktadır. Fakat bu yatırımların kendine özgü taşıdı̆̆g yüksek riskler, ilgili harcamaların finanse edilme imkânların daraltmakta ve AR-GE harcamaların finansal sistemin gelişmişsliğine bağıml hale getirmektedir. Çalışmada, hisse senedi piyasası ve kredi piyasası gelişsmişliği olmak üzere iki alt bileşen ile temsil edilen finansal gelişmişlik ve özel sektör AR-GE harcamalarının GSYIH'ya \% oranı arasındaki ilişkiler, Türkiye için 1990-2014 dönemi yıllık verileriyle eşbütünleşme, nedensellik, etki-tepki analizleri ve varyans ayrıştırması ile incelenmiştir. Ekonometrik analiz sonuçları; finansal gelişmişlik ve özel sektör AR-GE yoğunluğunun eşbütünleşik olduğunu ve aralarında pozitif bir ilişkinin bulunduğunu, uzun dönemde finansal gelişmişlikten kısa dönemde de hisse senedi piyasası gelişmişliğinden AR-GE yoğunluğuna doğru bir nedenselliğin varlı̆̆ını, finansal gelişmişlikteki artışın kısa dönemde $A R-G E$ yoğunluğunu da artırdığını ve finansal gelişmişliğin AR-GE yoğunluğundaki değişimleri büyük oranda açıkladığını göstermektedir. Çalışmanın sonuçları, işletmelerin özellikle hisse senedi piyasasında diş finansman olanakların artıracak politikaların AR-GE yatırımlarını da artırabileceğini ortaya koymaktadır.

Anahtar Kelimeler: Finansal gelişmişlik, AR-GE finansmanı, Eşbütünleşme, Nedensellik, Etkitepki analizi, Varyans ayriştırmast.

JEL Sinıflandırması: G10, G20, O16, O30.

The Impact Of Financial Development On Private R\&D Expenditures: Cointegration, Causality, Impulse-Response Analyses And Variance Decomposition For Turkey (1990-2014)

\section{ABSTRACT}

Intense competition in global markets forces private sector enterprises to allocate more sources to $R \& D$ investments. But specific high risks those investments carry lessen financing possibilities of related expenditures and make $R \& D$ expenditures dependent on development of financial system. In this article relations between financial development represented by two sub-components as credit market and stock market development and private sector $R \& D$ expenditure (\% of GDP) have been searched for Turkey with 1990-2014 annual data by using cointegration, causality, impulse-response analyses and variance decomposition. Econometric analysis results show that financial development and private sector $R \& D$ density are cointegrated, there is a positive relationship between these variables, causality in the long run from financial development and in the short run from stock market development to $R \& D$ density, a rise in financial development leads to a rise in $R \& D$ density in the short run and financial development is one of the sources of variation in $R \& D$ density. The results of article put forward that policies widening possibilities of external financial sources especially in stock market can increase volume of $R \& D$ investments.

Keywords: Financial development, $R \& D$ financing, Cointegration, Causality, Impulse-response analysis, Variance decomposition

Jel Classification: G10, G20, O16, O30.

\footnotetext{
* Yrd. Doç. Dr. N. Savaş Demirci, Kafkas Üniversitesi İktisadi ve İdari Bilimler Fakültesi , n.savas.demirci@gmail.com
} 


\section{GíRIŞ}

Son yıllarda işletmeler küresel piyasalarda rekabet avantajını elde etmek amaciyla inovasyon faaliyetlerine daha fazla yoğunlaşmakta, devletler de inovasyon faaliyetlerini desteklemek için ulusal politikalar oluşturmaktadır. İşletmelerin inovasyon stratejilerinin başlıca araçlarından biri olan araştırma ve geliştirme (AR-GE) yatırımlarının karakteristik özellikleri finansmanlarını zorlaş̧ırmakta ve ilgili yatırımlar için etkin finansal sistem zorunlu hale gelmektedir. Finansal gelişmişliğin inovasyon faaliyetlerinin özünü oluşturan AR-GE yatırımlarında yoğun olarak karşılaşılan finansman sorunlarını azaltma potansiyelinden hareketle, çalışma kapsamında ülkemiz Türkiye'de finansal gelişmişliğin özel sektör AR-GE harcamalarına etkisinin eşbütünleşme, nedensellik, etki-tepki analizleri ve varyans ayrıştırması ile incelenmesi amaçlanmakta ve bu alanda ülkemizdeki sınırlı literatüre de katk1 sağlanması hedeflenmektedir. Çalışmada öncelikle AR-GE yatırımlarına, AR-GE finansmanına ve finansal gelişmişliğe ilişkin kavramsal çerçeve sunulmakta, teorik ve ampirik literatür araştırılmakta ve daha sonra da 1990-2014 dönemine ilişkin ekonometrik analiz sonuçlarına yer verilmektedir.

\section{AR-GE YATIRIMLARI, AR-GE FINANSMANI VE FINANSAL GELIŞ̧MIŞLIIK}

İnsanoğlunun binlerce y1llık serüveninde toplumsal yapılar birçok değişime uğrarken ekonomiler de zaman içinde yapısal dönüşümler yaşamıştır. Tarım toplumlarında ekonomilerin başlıca kaynağı olan ekilebilir arazi, sanayileşmenin hızlanmasıyla yerini doğal kaynaklar ve işgücüne bırakmaya başlamış, günümüzde ise "bilgi'" ekonomilerin en önemli kaynağı haline gelmiş̧tir. Tarih boyunca bilgi, tüm üretim faaliyetlerinin bir parçası olmakla beraber özellikle Sanayi Devrimi'nden sonra bilginin ekonomilerde kullanım düzeyi artmaya başlamıştır. 1950'lerde günümüzün gelişmiş ülkelerinde bilgiye dayalı teknolojilerin ekonomik faaliyetlerde yoğun şekilde kullanılmaya başlaması, bu ülkelerin ekonomide dünya liderliğini ele geçirmelerine önemli katkılarda bulunmuştur. 1980'lerden itibaren de dünya genelinde hızlı bir şekilde gelişen bilgi ve iletişim teknolojilerine bağlı olarak bilgi edinme, kullanım ve paylaşım maliyetlerinin düşmesi ve küreselleşmeyle birlikte uluslararası ticari faaliyetlerin ve rekabetin artması paranın yanında bilgi transferini de kolaylaştırmış ve bilginin hem gelişmekte olan hem de gelişmiş ülkelerde ekonomik aktivitelerde kullanım oranı hızlı bir şekilde artmaya başlamıştır. 21. yüzyılda ise bilginin bir üretim faktörü olarak önemi ve beceri, öğrenme, organizasyon ve inovasyon üzerindeki artan etkileri geniş çevrelerce kabul görmektedir (Houghton ve Sheehan, 2000: 1,2,9; Powell ve Snellman, 2004: 199).

Bilgiye dayalı ekonomide piyasalar yeni rakiplerle küreselleşmekte, ürünlerin yaşam döngüsü kısalmakta, tüketicilerin yeni ürünlere talepleri artmakta ve teknolojiler daha kompleks hale gelmektedir. Bilginin alınıp satılabilen bir ürün haline geldiği 
“'Bilgi Ekonomisi’’nde, bilgi yaratmanın işletmeler açısından fark yaratan bir strateji konumuna erişmesi; temelinde bilgi üretmenin olduğu ve yeni fikirlerin işletmeye, tüketicilere ve diğer işletmelere değer katacak şekilde işletmenin ürünlerine, süreçlerine veya faaliyetlerinin diğer bileşenlerine uygulanması olarak tanımlanabilen inovasyonun da önemini artırmaktadır. Bilginin yönlendirdiği ekonomilerde işletmeler; bütünleşen piyasalarda uzun dönemde rekabet edebilme düzeylerini yükseltmek amaciyla verimliliklerini, kârlarını ve pazar paylarını artırmak için hem ürün ve hizmetlerinde hem de kurumsal kültürlerinde teknolojideki ve iş modellerindeki değişimleri birleştiren inovasyon faaliyetlerine daha fazla yoğunlaşmaktadır (European Commission, 2004: 5; Greenhalgh ve Rogers, 2010: 4). Birçok değişkenden etkilenmekle beraber temelde fikir ortaya koyma, konsept oluşturma, ürün geliştirme, ticarileştirme ve süreklilik sağlama şeklinde ilerleyen inovasyon süreci ve bu sürecin sonunda ortaya çıkarılan değer; inovasyon merkezli ülke ekonomilerini rekabet ve gelişmişlik açısından bir adım öne çıkarmaktadır (Berglund, 2007: 172). Yeni ürünlerin, yeni teknolojilerin, yeni sektörlerin, yüksek ücretli işlerin, refah artışının ve istikrarlı ekonomik büyümenin başlıca kaynağı olarak kabul edilen inovasyonların ülke ekonomilerine katkısına en iyi örnek Amerika Birleşik Devletleri'dir. ABD; araştırma, eğitim ve altyapı yatırımlarına yoğunlaşarak köklü girişimcilik kültürü, güçlü bilimsel altyap1, büyük teknoloji şirketleri, entelektüel sermaye koruma kanunları, etkin finansal piyasalar, iş dünyasıüniversite işbirliği ve teknoloji tabanlı süreçlerin başarılı yönetimi ile İkinci Dünya Savaşı'ndan sonra dünyada inovasyon liderliğini ve verimlilik artışlarıyla ekonomi alanında liderliği yakalamış ve günümüzde de en inovatif (yenilikçi), en eğitimli ve en rekabetçi ülkeler arasında kendine yer bulmuştur (Atkinson ve Wial, 2008: 4,7,8; U.S. Department Of Commerce, 2012: 1,14,17). ABD'nin mevcut ekonomik durumu; Joseph Schumpeter'in girişimcilik ve inovasyon odaklı kalkınma teorisiyle de örtüşmektedir. Schumpeter ilk olarak 1911'de Almanca 1934'te de İngilizce olarak yayımlanan Ekonomik Gelişme Teorisi adlı çalışmasında, süreç inovasyonu gerçekleştiren işletmelerin rakiplerine maliyet avantajı sağlamak yoluyla üstünlük kurabileceğini, ürün inovasyonu gerçekleştiren işletmelerin ise piyasada yüksek bir paya ulaşabileceğini ve bu işletmelerin elde edecekleri kazançların diğer işletmeleri de inovasyona yönlendireceğini ve sonuçta gelişmekte olan bir ekonominin hızlı bir büyüme sürecine gireceğini öngörmüştür. Diğer taraftan modern içsel büyüme teorisi de ekonomik büyümenin kaynağı olarak inovasyona yer vermektedir. İlk olarak Romer'in (1986) modellediği ve Lucas (1988), Romer (1990), Grossman ve Helpman (1991) ve Aghion ve Howitt (1992) gibi ekonomistlerin savunduğu yeni içsel büyüme teorisine göre; ekonomik büyüme asıl olarak pozitif dışsallıklar yoluyla, beşeri sermaye yatırımları ve inovasyonlar sonucu içsel süreçlerde ortaya çıkan yeni teknolojiler ve verimlilik artışlarından kaynaklanmaktadır. Romer araştırmaya ve beşeri sermayeye yapılan yatırımlarla ortaya çıkan inovasyonların, verimlilik artışları ve teknolojik gelişmeler kanallarıyla ekonomik büyümeyi sağlayacağını savunmuştur. Lucas, eğitimin ve 
yaparak-öğrenmenin beşeri sermayeyi artırdığını ve bu durumun da verimliliği ve teknolojiyi hızlandırdığını belirtmiştir. Grossman ve Helpman'a göre araştırma ve geliştirme harcamalarıyla gerçekleştirilen inovasyonlar, yeni bilgiler üreterek teknolojik ilerlemelerle ekonomik büyümeyi sağlamaktadır. Aghion ve Howitt de kurdukları modelde eğitimli işgücüyle ve yüksek verimlilikle çalışan bir araştırma ve geliştirme sektörünün inovasyonlar yoluyla yeni teknolojiler üreteceğini öne sürmüştür.

İnovasyon faaliyetleri, işletmelerin ürün ve hizmetlerini, üretim ve dağıtım kanallarını yenilemediği sürece uzun dönemde hayatta kalamayacağı gerçeğinden hareketle, sadece yüksek teknolojili sektörlerde değil tüm sektörlerde zorunlu hale gelmektedir. Artan inovasyon faaliyetlerinin paralelinde rekabetçi bir piyasayla, risk alabilen girişimcilerle ve inovasyonları destekleyen kuruluşlarla ortaya çıkabilen inovatif bir toplum oluşturmak ve uzun dönemde rekabet gücünü artırmak için yerel, bölgesel, ulusal ve uluslararası düzeyde inovasyon politikaları dünya genelinde daha sık oluşturulmaktadır (Elg, 2014: 9,14,47). Bilimsel çalışmaların, teknolojinin ve üretim süreçlerinde müşterilerle ve tedarikçilerle ilişkilerin yanında bilgi kaynaklarından biri olan araştırma ve geliştirme (AR-GE), inovasyon sistemleri oluşturmak için inovasyon faaliyetlerinin sayısını ve verimliliğini artırmak amacıyla oluşturulan politikalar bütünü olan inovasyon politikaları uygulamalarında başlıca politika araçlarından biri konumunda bulunmaktadir (Lundvall, 2004: 16; European Commission, 2000: 9). ARGE, dar anlamda işletmeler ve diğer birimler tarafından yeni ve geliştirilmiş ürün ve süreçler yaratmak amaciyla gerçekleştirilen faaliyetlerken geniş anlamda ise üniversitelerde ve laboratuarlarda ticari kullanımdan önce ürünleri denemeye ve geliştirmeye yönelik tüm temel bilimsel araştırma faaliyetleridir. Temel araştırma, uygulamalı araştırma ve geliştirme olmak üzere üç safhadan oluşan AR-GE'ye ilişkin harcamalar; işletmelerin, sektörlerin ve ülkelerin inovasyon performanslarını ölçmek için en sık kullanılan göstergelerden biridir (Hall, 2006: 1-2). AR-GE harcamaları; devlet politikaları, kalifiye teknik personel havuzu ve pazara erişim ile birlikte inovasyon kapasitesini artırmak ve inovasyonu hızlandıran bir ortam kurmak için gereklidir. Diğer taraftan AR-GE'ye yatırım yapılmadan da inovasyonlar gerçekleştirilebilmekle beraber bu harcamalar ve inovasyon sayısı arasında genellikle pozitif bir korelasyon bulunmaktadır (U.S. National Science Board, 2012: 1,4). Ülkü'nün (2004) OECD (Ekonomik Kalkınma ve İşbirliği Örgütü) ve G-7 ülkelerinde AR-GE harcamalarının patent sayısı ile ifade edilen inovasyonları pozitif olarak etkilediği yönünde sonuçlara ulaşması ve Hall, Lotti ve Mairesse'nin (2012) İtalya imalat sanayi sektöründeki işletmelerde AR-GE harcamalarının inovasyon gerçekleştirme olasılığını büyük oranda etkilediğini ortaya koymaları söz konusu ilişkiyi desteklemektedir. Yine AR-GE harcamalarının ekonomik büyümeyi ve işletme performansını da pozitif olarak etkilediğini ortaya koyan birçok ampirik çalışma da 
bulunmaktadır $^{1}$. Bu bağlamda 2013 itibariyle AR-GE harcamalarının Gayri Safi Yurtiçi Hasılası'na (GSYİH) oranı en yüksek ülkelere bakıldığında Çin Halk Cumhuriyeti dışında tümünün gelişmiş ülkeler kategorisinde olduğu görülmektedir.

Grafik 1. AR-GE Harcamalarının GSYIH'sına Oranı En Yüksek 20 Ülke (2013)

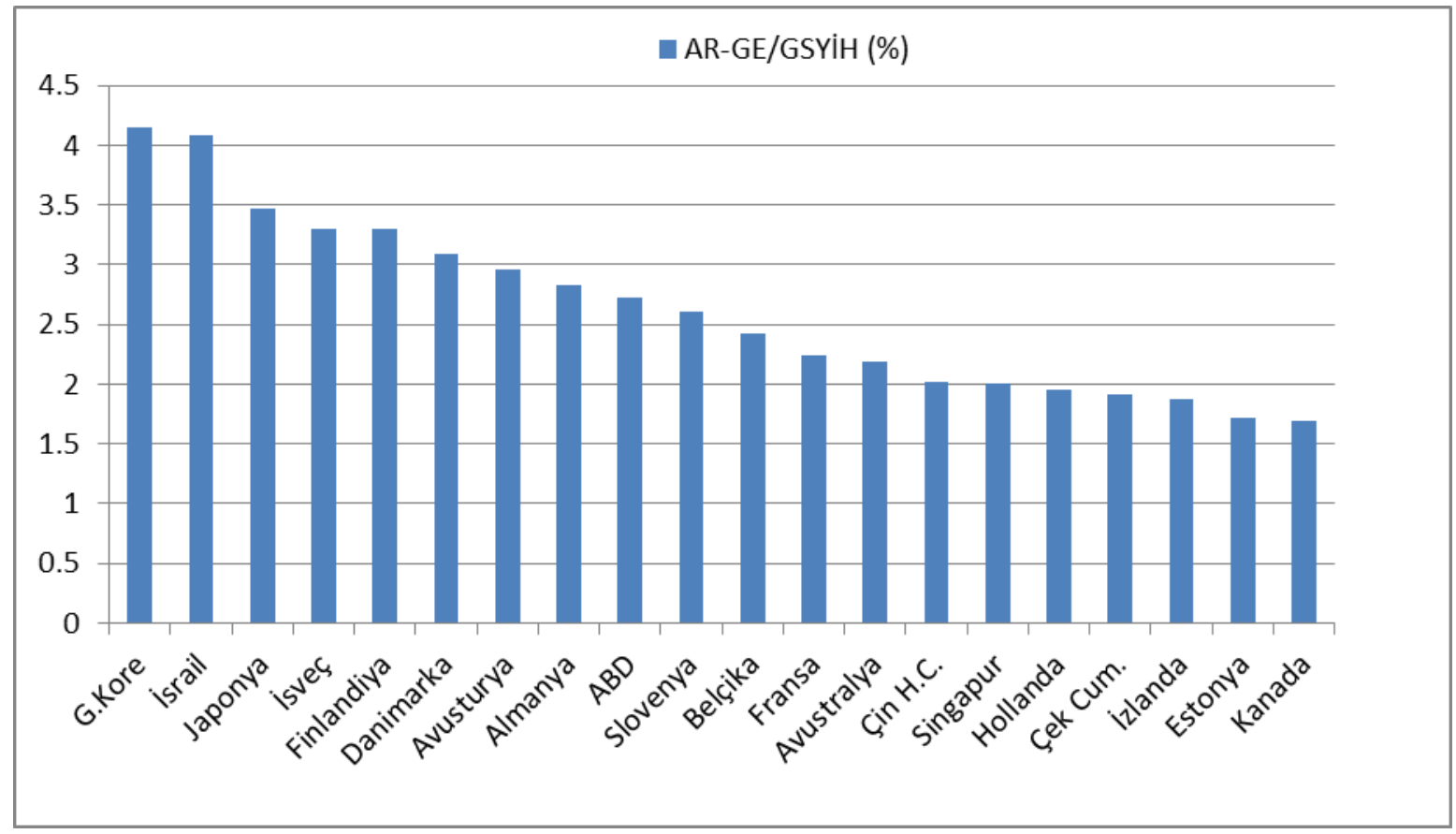

Kaynak: databank.worldbank.org

Grafik 1'e göre dünyanın önde gelen refah ülkeleri AR-GE'ye yüksek oranlarda yatırım yapmaktadır. İlk sıradaki Güney Kore kalkınma hikâyesiyle de bir adım öne çıkmaktadır. 1960'lardan itibaren ihracata yönelik hafif/ağır sanayi ve teknoloji yoğun sanayi yatırımları ile yüksek hızlarda büyüyen Güney Kore, özellikle 2000'lerden sonra inovasyon merkezli kalkınma politikaları çerçevesinde AR-GE harcamalarının GSYİH'ya oranını yaklaşık iki katına çıkararak bu alanda dünya liderliğini ele geçirmiştir. Ayrıca Slovenya, Estonya ve Çin Halk Cumhuriyeti de son yıllarda AR-GE yatırımlarını ciddi oranda artırmıştır. Türkiye ise son dönemde AR-GE yatırımlarını artırmakla beraber yaklaşık \%1'lik oranıyla halen önde gelen gelişmiş ülkelerin oldukça gerisindedir. Türkiye İstatistik Kurumu'nun (TÜİK) 2014 verilerine göre AR-GE harcamalarının \%50'sinin özel sektör, \%40'ının yükseköğretim ve \%10'unun kamu tarafından gerçekleştirildiği ülkemizde etkin bir ulusal inovasyon sisteminin ve politikasının bulunmaması ve inovasyon kültürünün yerleşmemiş olması, AR-GE harcamalarının da göreceli düşük kalmasına neden olmaktadır.

Hem işletmeler hem de ulusal ekonomiler için son derece stratejik bir unsur konumunda bulunan AR-GE yatırımları, diğer yatırımlardan birçok noktada ayrışmakta

\footnotetext{
${ }^{1}$ AR-GE harcamalarının ekonomik büyümeye ve işletme performansına pozitif etkisi üzerine ayrıntılı literatür taramaları için bkz: Khan (2015) ve Ayaydın ve Karaaslan (2014)
} 
ve bu yatırımların kendine özgü özellikleri finansmanını zorlaştırmaktadır. Hall'a (2002) göre AR-GE yatırımlarına ilişkin harcamaların en az \%50'sini bilim insanları ve yüksek eğitimli mühendislere yapılan yüksek tutarlı ödemeler oluşturmakta, yapılan harcamaların işletmelere kâr/katma değer olarak geri dönmesi uzun yıllar sürebilmekte ve ilgili süreçte ortaya çıkarılan bilginin çalışanların beşeri sermayesine eklenmesi bu yatırımların riskliliğini artırmaktadır. Özellikle AR-GE harcamalarına ait ayarlama maliyetlerinin yüksek olması yatırımların minimum getiri oranını yükseltmekte ve harcamaların kısa dönemde maliyet değişimlerine yavaş tepki vermesi sermaye maliyetine etkisini belirsizleştirmektedir. Yine aynı yazara göre AR-GE harcamalarının bir diğer karakteristik özelliği de somut çıktı ortaya koyamama olasılığıdır. Sonuçta AR-GE yatırımlarının genellikle yüksek tutarlı olması, batık maliyetlerinin yüksekliği, teminat değerinin düşüklüğü ve geleceğe dair içerdiği yoğun belirsizlikler; her yatırım gibi finanse edilmek zorunda olan AR-GE faaliyetlerinin finansman olanakların özellikle gelişmemiş finansal sistemlerde daraltmaktadır. Öte yandan bu projelere finansman sağlayacak kaynağın projenin gerçek potansiyelini çoğunlukla bilememesi paralelinde ortaya çıkan asimetrik bilgi sorunu da AR-GE projelerinde daha yoğun yaşanmaktadır. Bu bağlamda gelişmiş bir finansal sistem; AR-GE projelerine ilişkin asimetrik bilgi sorununun etkilerini ve işlem ve temsil maliyetlerini azaltarak, yüksek riski dağıtarak ve yüksek tutarlı inovatif faaliyetlere ve yeni ürünleri/yeni teknolojileri ortaya çıarabilecek en inovatif şirketlere fon aktararak AR-GE projelerinin finansmanını kolaylaştırma ve AR-GE harcamalarını artırma noktasında önemli hale gelmektedir.

İnsanoğlu yüzyıllardan beri yatırımlarını finanse etmek için arayışlara girmiş, fon aktarma mekanizmaları kurmuş ve kaynak sağlamak için finansal işlemler gerçekleştirmiş olmakla beraber özellikle 20.yüzyılın ikinci yarısından itibaren telekomünikasyon ve bilgi işlem alanlarında teknolojik gelişmelerin hız kazanması; finansal hizmetler sektöründe işlem maliyetlerinin düşmesine ve finansal inovasyonların artmasına neden olmuştur. Maliyetlerin düşmesi, teknolojinin gelişmesi ve finansal sektörde rekabetin hem ulusal hem de uluslararası düzeyde giderek artması; özel sektör kuruluşlarında ve devletin düzenleyici kurumlarında modern değişimlerin önünü açmıştır. İlgili gelişmelerle birlikte de finansal piyasalar ve finansal aracılar günümüzde birbirlerine bağlanmış ve dünya genelinde finansal sistemler bütünleşmiş̧tir (Merton ve Bodie, 1995: 3-7). Fon fazlas1 ekonomik birimlerden fon ihtiyac1 olan ekonomik birimlere kaynak aktarımını sağlayan, devletin kilit bir yapı olarak yer aldığı ve diğer ülkelerin finansal ekonomileriyle yakın ilişki içinde bulunan mekanizma olarak tanımlanabilen ve ticari faaliyetlerin etkinliği için gerekli olan finansal sistem; finansal aracılar, finansal piyasalar ve düzenleyici/denetleyici kurumlardan oluşur (Allen ve Gale, 2001: 1; Allen vd., 2012: 6). Ekonomilerinin temel yapı taşı olarak kabul edilen finansal sistemin işlevleri aşağıdaki gibi sınıflandırılabilir (Levine, 1997: 691; Stiglitz, 1998: 1): 
- Finansal riskleri transfer eder, dağıtır, azaltır ve risk yönetimi uygulamalarını geliştirir

- Tasarrufları harekete geçirerek kaynakların rasyonel dağıtımına yardımcı olur kolaylaştırır

Bilgi ve işlem maliyetlerini düşürerek finansal bilginin aktarımını

- $\quad$ Likiditeyi artırarak mal ve hizmet ticaretini hareketlendirir

- Finansal sözleşmeler yardımıyla kurumsal kontrolü güçlendirir

Finansal sistem içerisinde finansal araçların, piyasaların ve aracıların bilgi, işlem ve uygulama maliyetlerini düşürdüğünde ve finansal sistemin her bir işlevinde ilerlemeler yaşandığında ortaya çıktığı kabul edilen finansal gelişmişlik; gelecekteki ekonomik büyümenin, sermaye birikiminin ve teknolojik gelişmenin de iyi bir göstergesidir (Levine, 1997: 689; Levine, 2005: 869-870). Finansal gelişmişlik; yatırım ve büyüme sürecine katkıda bulunan kurumların, araçların ve piyasaların gelişmesi olarak ve iyi projelere sahip ekonomik birimlerin uygun şartlarda finansman sağlayabildikleri, yatırımcıların güven içinde uygun getiri sağladıkları ve ilgili finansal işlemlerin düşük risk ve düşük maliyetle gerçekleştirildiği bir finansal sistemin varlığı olarak da ifade edilebilebilir (Rajan ve Zingales, 2003: 9; Fitzgerald, 2006: 1). Gelişmiş bir finansal sistem en verimli ve en yüksek getirili yatırımlara kaynak transferini sağlarken, gelişmemiş bir finansal sistem ise genellikle düşük verimli yatırımlara kaynak aktararak ekonomik büyüme ve refah artışı sürecini olumsuz olarak etkileyebilmektedir (Stiglitz, 1998: 1).

Finansal sistemin başlıca iki piyasası olan kredi piyasası ve hisse senedi piyasası gelişmişliği ekseninde ele alınan finansal gelişmişlik; özellikle verimlilik artışının, istihdamın ve yüksek ücretlerin kaynağı olarak kabul edilen özel sektör yatırımlarının finanse edilmesi için son derece önemlidir. Kredi piyasası gelişmişliğini temsilen finansal kurumlarca özel sektöre kullandırılan yurt içi kredi hacminin GSYIH'ya oranına bakıldığında, ülkemizin üst-orta gelirli ülkelerle büyük oranda benzer büyüme seyri izlediği görülmektedir: 
Grafik 2. Türkiye'de Finansal Kurumlarca Özel Sektöre Kullandırılan Yurt İçi Kredi Hacmi/GSYİH Oranı (\%) (2003-2014)

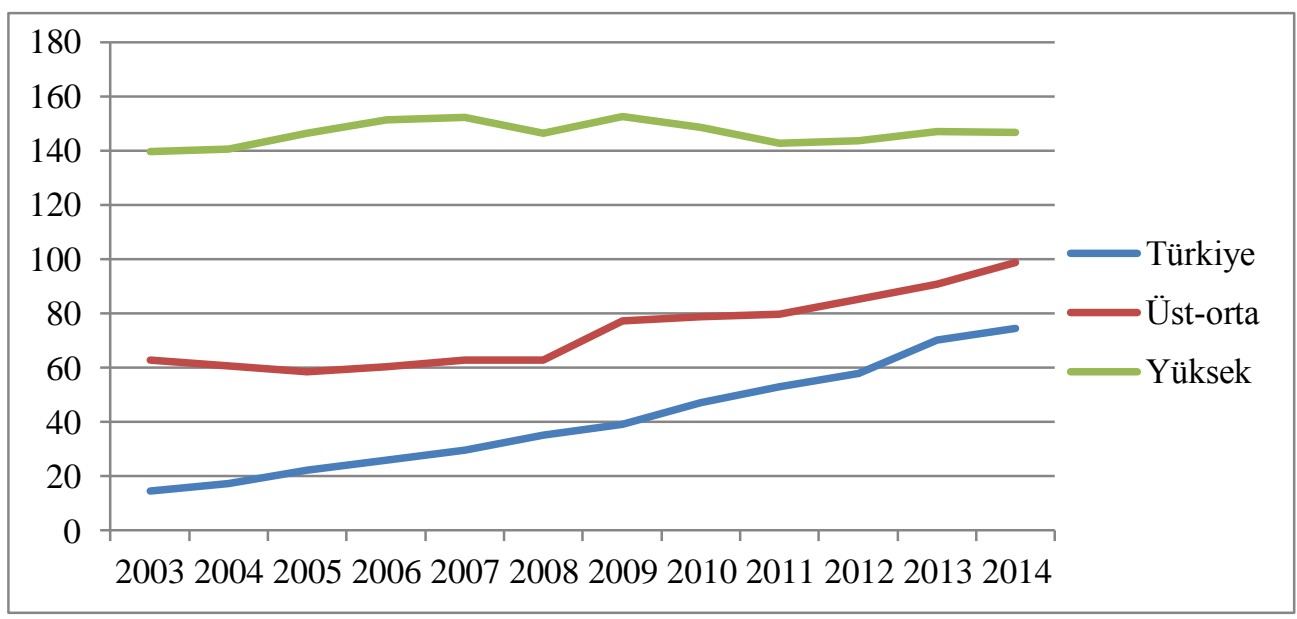

Kaynak: databank.worldbank.org

Türkiye'de özel sektör kredi hacmi/GSYİH oranı ülkemizde 2003'te \%15'e yakınken, aynı oran 2014 'te $\% 75^{\prime}$ lere dek çıkmıştır. Ülkemizde kredi piyasası gelişmişliği özellikle 2000'li yılların başından itibaren bankacılık sistemindeki reformlar ve göreceli düşük kredi faiz oranlarıyla birlikte istikrarlı bir şekilde artmakla beraber, hem üst-orta gelirli hem de yüksek gelirli ülke ortalamalarının gerisinde kalmaktadır. İlgili oranın yüksek gelirli ülkelerde durgun bir seyir izlemesi, gelişmiş ülkelerdeki düşük ekonomik büyüme oranları ve daralan iç piyasalar ile açıklanabilir. Diğer taraftan hisse senedi piyasası gelişmişliğini ifade eden hisseleri borsada işlem gören yerel şirketlerin piyasa değerinin GSYİH'ya oranı incelendiğinde, ülkemizde ilgili oranının gelişmiş ülkelerin oldukça gerisinde olduğu ve 2007 'de ortaya çıkan küresel finansal krizin negatif etkileri açıkça görülmektedir.

Grafik 3. Türkiye'de Hisseleri Borsada İşlem Gören Yerel Şirketlerin Piyasa Değeri/GSYİH Oranı (\%) (2003-2014)

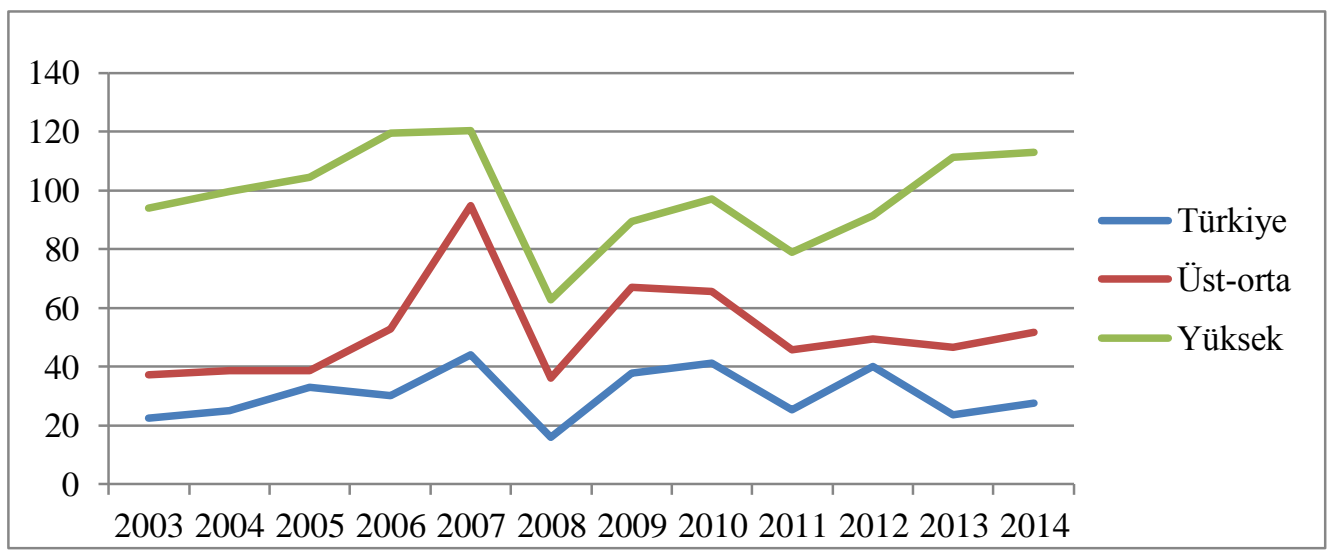

Kaynak: databank.worldbank.org 
2007 yılında A.B.D. konut piyasasında ortaya çıkan, kısa sürede önce tüm A.B.D. finansal sistemini ve daha sonra da diğer ülke ekonomilerini olumsuz etkileyen ve dünya finans tarihinin en büyük krizlerinden biri olarak kabul edilen kriz, tüm dünyada olduğu gibi ülkemizde de piyasa kapitalizasyonunun milli gelire oranının düşmesine neden olmuştur. İlgili oran 2014 itibariyle ülkemizde, üst-orta ve yüksek gelirli ülkelerde 2007'ye göre çok az artış göstermiştir.

\section{FINANSAL GELİŞMIŞLİĞIN ÖZEL SEKTÖR AR-GE HARCAMALARINA ETKISİ}

\subsection{Teorik Literatür}

Finansal gelişmişliğin özel sektör AR-GE harcamalarına etkisi; teorik açıdan çoğunlukla iç kaynakların yetmediği durumlarda borç ve dış kaynaklardan sağlanan özkaynak alternatifleri ekseninde bankaların başını çektiği kredi piyasasının ve hisse senedi piyasasının ilgili harcamalara etkisine dayanmaktadır. Fazzari, Hubbard ve Petersen (1988), Hall (1992) ve Himmelberg ve Petersen (1994); AR-GE yatırımlarında diğer yatırımlara göre asimetrik bilgi ve temsil maliyeti sorunlarıyla daha fazla karşılaşıldığından dış kaynakların (borç veya özkaynak) maliyetinin daha yüksek olabildiğini ve bu durumda da dağıtılmayan kârlara bağgl olarak pozitif nakit akışlarının ön plana çıktığını savunmuşlardır. Fakat özellikle küçük ve yeni kurulan işletmelerde yeterli otofinansman olanakları bulunmamakla birlikte işletmelerde dağıtılmayan kârların uzun yıllar riskli AR-GE yatırımlarına bağlanması, finansal sorunlar ortaya çıarabilmektedir. Brown, Fazzari ve Petersen'e (2009) göre, iç kaynakların yetersiz olduğu durumlarda başvurulabilecek finansman opsiyonlarından borç finansmanı ise AR-GE yoğun yeni kurulan ve küçük işletmeler için yetersiz teminat, belirsiz getiri oranları ve bilgi problemleri nedeniyle çok cazip değildir. Hall ve Lerner'e (2010) göre de yabancı kaynaklarla finansman sabit ve düzenli kredi geri ödemeleri gerektirdiğinden doğası gereği AR-GE yatırımlarının finansmanı için uygun değildir. Bu durum da özkaynak finansmanı karşısında borç finansmanının çekiciliğini azaltır. Kerr ve Nanda (2015), yabancı kaynaklarla finansmanın özellikle stabil nakit akışlarına ve yeterli teminata sahip büyük işletmeler için daha uygun olduğunu ve kredi piyasasının büyümesinin bu tür işletmelerin AR-GE harcamalarını artırabileceğini öne sürmüşlerdir. Brown, Martinsson ve Petersen (2012) ise düzenli geri ödeme gerektirmemesine ek olarak ortakların olası yüksek getiri oranlarına ortak olması, maddi teminata ihtiyaç duyulmaması ve ortak sayısının artmasının özellikle AR-GE projeleri için sorun yaratabilecek kayda değer finansal problemlere neden olmamasıyla ilişkili olarak hisse senedi piyasasının gelişmesinin AR-GE harcamalarını artırabileceğini savunmuşlardır. Diğer taraftan halka açılmanın getireceği vekalet maliyetleri ve çıkarım giderleri de özellikle kü̧̈ük işletmeler için kısıtlayıcı olabilmektedir. 


\subsection{Ampirik Literatür}

Finansal gelişmişliğin özel sektör AR-GE harcamalarına etkisini inceleyen çok fazla ampirik çalışma bulunmamakla beraber Türkiye üzerine yapılan çalışmalarda da ülkemize ait veriler diğer ülke verileriyle birlikte analiz edilmiş ve inovasyonların asıl kaynağı olarak kabul edilen özel sektör harcamaları yerine tüm AR-GE harcamaları dikkate alınmıştır. Söz konusu ilişkiyi konu alan az sayıdaki çalışmanın yazarlarından Pienknagura (2010), 47 ülkeden 20.000 bine yakın işletmenin verilerini doğrusal regresyon analizinde kullandığı araştırmasında özel sektör kredilerinin GSYİH'ya oranı, piyasa kapitalizasyonunun GSYİH'ya oranı ve muhasebe standartlarının kalitesi ile ayrı ayrı ölçtüğü finansal gelişmişliğin; işletmelerin AR-GE harcamalarının satışlara oranını pozitif olarak etkilediğini bulmuştur. Maskus, Neumann ve Seidel (2010), 18 OECD ülkesinde 22 imalat sanayi sektöründeki yaklaşık 4.000 işletmenin verilerini panel veri analizinde kullanmışlar ve likit varlıkların, özel sektör kredilerinin, hisse senedi piyasası ve özel sektör tahvil piyasası kapitalizasyonunun GSYİH'ya oranının dış kaynaklara bağımlılığı yüksek sektörlerde AR-GE harcamalarının sektör çıktısına oranını pozitif olarak etkilediğini sonucuna ulaşmışlardır. Akıncı, Akıncı ve Yılmaz (2014), OECD ülkelerinin 1960-2012 yılları arasında farklı dönemlere ait yıllık verilerini panel veri analiziyle incelemişler, finansal gelişmişliği temsilen yurt içi banka kredilerinin GSYİH'ya oranını kullanmışlar, finansal gelişmişliğin AR-GE harcamalarının GSYİH'yı oranını ve bir milyon kişiye düşen AR-GE faaliyetlerinde çalışan sayısını pozitif olarak etkilediğini belirtmişlerdir. Aynı yazarlar finansal gelişmişlik ve AR-GE göstergeleri arasında eşbütünleşme ilişkisine ve finansal gelişmişlikten her iki AR-GE göstergesine doğru da nedensellik ilişkilerine ulaşmışlardır. Helhel (2016) de, E-7 ülkelerinin 2001-2013 yıllarına ait yıllık verilerini panel veri analiziyle araştırmış, finansal gelişmişliği temsilen yurt içi banka kredilerinin GSYİH'ya oranını ve geniş anlamda para arzının (M2) GSYİH'ya oranını kullanmış, finansal gelişmişliği temsil eden değişkenlerin AR-GE harcamalarının GSYİH'yı oranını ve bir milyon kişiye düşen AR-GE faaliyetlerinde çalışan sayısını pozitif olarak etkilediğini bulmuş, finansal gelişmişlik değişkenleri ve AR-GE göstergeleri arasında eşbütünleşme ilişkisine ulaşmış ve banka kredileri oranından her iki AR-GE göstergesine, geniş para arzı oranından da bir milyon kişiye düşen AR-GE çalışanı sayısına doğru nedensellik ilişkilerinin varlı̆̆ını ortaya koymuştur.

\section{EKONOMETRÍK ANALIZ}

\subsection{Veri Seti}

Finansal gelişmişliğin AR-GE harcamalarına etkisini ve finansal gelişmişlik ve AR-GE harcamaları arasındaki kısa ve uzun dönemli dinamik ilişkileri; verimlilik artışının, istihdamın, yüksek ücretlerin ve inovasyonların başlıca kaynağı olarak kabul edilen özel sektör açısından incelemeyi amaçlayan bu ekonometrik analizde; 1990-2014 
dönemine ait Türkiye'ye ilişkin yıllık veriler kullanılmış ve finansal gelişmişlik kredi piyasası gelişmişliği ve hisse senedi gelişmişliği olmak üzere iki alt bileşenle temsil edilmiştir. Finansal sistemin hisse senedi piyasasıyla birlikte iki ana piyasasından biri olan kredi piyasası gelişmişliği finansal kurumlarca özel sektöre kullandırılan yurt içi kredi hacminin GSYİH'ya \% oranıyla, hisse senedi piyasası gelişmişliği ise hisseleri borsada işlem gören yerel şirketlerin piyasa değerinin GSYİH'ya \% oranı ile ifade edilmiştir. Ülkemizde özel sektör tahvil piyasası yok denecek seviyede olduğundan, özel sektör tahvil piyasası kredi piyasasında ayrı bir piyasa olarak dikkate alınmamıştır. AR-GE harcamaları ise AR-GE yoğunluğu olarak da isimlendirilen özel sektör AR-GE harcamalarının GSYİH'ya \% oranı olarak analize dahil edilmiştir. AR-GE harcamalarına ilişkin veriler 1990 yılından itibaren düzenli olarak yayımlandığından, veri seti 1990-2014 yıllarını kapsamaktadır. Tüm seriler doğal logaritmaları alınarak analizlere dahil edilirken, kredi piyasası gelişmişliği LFD1, hisse senedi piyasası gelişmişliği LFD2, AR-GE yoğunluğu ise LRE şeklinde kısaltılarak kullanılmıştır. Toplam 25 yılı kapsayan her 3 değişkene ait veri seti, TÜIK' 'in ve Dünya Bankası'nın web sitelerinden elde edilmiştir. Kurulan ekonometrik modellerin tahmininde ve diğer analizlerde Eviews 9 ekonometrik analiz programından yararlanılmıştır.

\subsection{Yöntem ve Analiz Sonuçları}

\subsubsection{Durağanlık Testleri}

Durağanlık; zaman serisinin sabit ortalamaya, sabit varyansa ve değeri zamana değil iki zaman periyodu arasındaki gecikmeye bağlı olan kovaryansa sahip olma durumudur. Durağanlık koşullarını sağlamayan zaman serileri durağan dışıdır ve birim köke sahiptir (Asteriou ve Hall, 2007: 231). Birçok zaman serisi özellikle iktisadi ve finansal seriler birim köke sahiptir. Granger ve Newbold (1974); durağan olmayan zaman serilerine ilişkin verilerle ekonometrik analizler yapılmasının, yüksek açıklama gücü ve anlamlı değerlere ulaşıldığı fakat sonuçları yorumlamanın anlamsız hale geldiği sahte regresyon problemine neden olabileceğini belirtmişlerdir. Sahte regresyon problemiyle ve doğru olmayan sonuçlarla karşılaşmamak için model tahmininden önce serilerin birim köke sahip olup olmadığına bakılması gerekir. Durağan olmayan seriler (Xt) 1.farkları alındığında genellikle durağan hale gelirler $(\Delta \mathrm{Xt}=(\mathrm{Xt}-\mathrm{Xt}-1), \Delta$ : fark operatörü, Xt-1: bir dönem gecikmeli değer). Fark alma işlemiyle 1.farkı $(\Delta \mathrm{Xt})$ durağan hale gelen orijinal seriye $(\mathrm{Xt}) 1$. dereceden bütünleşik seri denir ve seri $\mathrm{I}(1)$ şeklinde ifade edilirken düzey değerinde durağan olan bir seri ise $\mathrm{I}(0)$ şeklinde gösterilir. Serilerin durağan olup olmadıklarının tespitine yönelik çeşitli yöntemler bulunmaktadır ve sık kullanılan yöntemlerin başında birim kök testleri gelmektedir. Birim kök testleri en genel haliyle aşağıda ifade dilen otoregresif AR(1) modeli üzerine kurulur (Gujarati, 2003: 814; Hansen, 2016: 309):

$$
\mathrm{X}_{\mathrm{t}}=\alpha \mathrm{X}_{\mathrm{t}-1}+\varepsilon_{\mathrm{t}}\left(\varepsilon_{\mathrm{t}} \text { beyaz gürültü hata terimidir }\right)
$$


Çalışmada serilerin durağan olup olmadıklarının tespiti için ADF (Artırılmış Dickey-Fuller) birim kök testi kullanılmış, maksimum gecikme uzunlukları 1 olarak alınmıştır:

Tablo 1. ADF birim kök testi

\begin{tabular}{|c|c|c|c|c|}
\hline \multirow{3}{*}{ Değişken } & \multicolumn{2}{|c|}{ Düzey } & \multicolumn{2}{|c|}{ 1.Fark } \\
\hline & \multicolumn{2}{|c|}{ t-istatistiği (p-değeri) } & \multicolumn{2}{|c|}{ t-istatistiği (p-değeri) } \\
\hline & Sabitli & Sabitli trendli & Sabitli & Sabitli trendli \\
\hline LFD1 & $\begin{array}{c}0,272 \\
(0,9713) \\
\text { Kritik değer } \% 5= \\
-2,998\end{array}$ & $\begin{array}{c}-1,151 \\
(0,8969) \\
\text { Kritik değer } \% 5= \\
-3,622\end{array}$ & $\begin{array}{c}-3,056 \\
(0,0451) \\
\text { Kritik değer \%5= } \\
-3,004\end{array}$ & $\begin{array}{c}-3,647 \\
(0,0486) \\
\text { Kritik değer } \% 5= \\
-3,632\end{array}$ \\
\hline LFD2 & $\begin{array}{c}-2,246 \\
(0,1964) \\
\text { Kritik değer } \% 5= \\
-2,998\end{array}$ & $\begin{array}{c}-3,212 \\
(0,1066) \\
\text { Kritik değer } \% 5= \\
-3,622\end{array}$ & $\begin{array}{c}-6,688 \\
(0,0000) \\
\text { Kritik değer } \% 5= \\
-3,004\end{array}$ & $\begin{array}{c}-7,111 \\
(0,0000) \\
\text { Kritik değer } \% 5= \\
-3,632\end{array}$ \\
\hline LRE & $\begin{array}{c}-0,094 \\
(0,9390) \\
\text { Kritik değer \%5= } \\
-2,998\end{array}$ & $\begin{array}{c}-2,551 \\
(0,3032) \\
\text { Kritik değer } \% 5= \\
-3,622\end{array}$ & $\begin{array}{c}-3,736 \\
(0,0107) \\
\text { Kritik değer } \% 5= \\
-3,004\end{array}$ & $\begin{array}{c}-3,810 \\
(0,0355) \\
\text { Kritik değer } \% 5= \\
-3,632\end{array}$ \\
\hline
\end{tabular}

Her 3 değişkenin düzey değerlerinde sabitli ve sabitli trendli modeller için serilerin birim kök içerdiğini ifade eden sıfır hipotezleri reddedilememişken, 1.farkları alındığında her üç modelde de birim kökün varlığını ifade eden $\mathrm{H}_{0}, \% 5$ anlamlılık düzeyinde reddedilmiştir. Diğer bir ifadeyle düzeyde durağan olmayan LFD1, LFD2 ve LRE serileri 1.farkları alındıktan sonra durağan hale gelmiştir. 1.farklarında durağan olan serilere eşbütünleşme analizi yapılabilmektedir.

\subsubsection{Eşbütünleşme Testi}

Birim köke sahip olmayan düzeyde durağan $\mathrm{I}(0)$ seriler, regresyon analizinde kullanılabilirken durağan dışı serilerin bu şekilde regresyon analizine dahil edilmesi, sahte regresyon sorununa neden olabilmektedir. Sahte regresyondan kaçınmak için modelde farkları alınarak durağanlaştırılan serilerin kullanılması gerekir fakat fark alarak durağanlaştırma işlemi seriler arasındaki uzun dönemli ilişkiye ait olası bilgileri ortadan kaldırır (Maddala, 1992: 588; Wooldridge, 2012: 646). Eğer 1.dereceden bütünleşik serilerin arasında durağan doğrusal bir ilişkiye ulaşılıyorsa durağan dışı bu seriler eşbütünleşik olarak kabul edilir. (Wang, 2009: 49). İlk olarak Granger (1981) tarafından kavram olarak ortaya konan eşbütünleşme, Engle ve Granger'ın (1987) çalışmalarında teorik olarak modellenmiştir. Eşbütünleşik seriler arasındaki uzun dönemli ilişkiyi ortaya koyan eşbütünleşme regresyonunun tahmini ile elde edilen regresyon sonucuna da eşbütünleşme denklemi denir. Eşbütünleşmeyi ifade eden eşbütünleşme vektör sayısı, uzun dönem modelinde yer alan bütünleşik değişken sayısının en fazla 1 eksiği kadar olabilir. Eşbütünleşme vektör sayısı, eşbütünleşme 
rankı olarak da ifade edilir. Birim köke sahip iki veya daha fazla sayıdaki zaman serisi arasındaki ilişkiyi analiz etmek için eşbütünleşme analizine ihtiyaç duyulur (Greene, 2003: 652; Gujarati, 2003: 822; Asteriou ve Hall, 2007: 319).

Eşbütünleşme ilişkisinin araştırılması amacıyla çeşitli yöntemlerden yararlanılmaktadır. Engle ve Granger (1987) tarafından geliştirilen statik yöntemlerin yanında Johansen $(1988,1991)$ ve Johansen ve Juselius (1990) tarafindan geliştirilen dinamik Johansen yöntemi de sıklıkla tercih edilmektedir. Maksimum olabilirlik tahmincisini kullanan Johansen yöntemi; $N$ sayıda seri içeren, $\rho$ gecikmeli çok değişkenli kısıtlanmamış bir vektör otoregresif (VAR) modele dayanmaktadır.

$$
\Delta \mathrm{Z}_{\mathrm{t}}=\Pi \mathrm{Z}_{\mathrm{t}-1}+\sum_{i=1}^{p-1} \Gamma_{\mathrm{i}} \Delta \mathrm{Z}_{\mathrm{t}-\mathrm{i}}+\varepsilon_{\mathrm{t}}
$$

$Z_{t}$, değişkenler vektörünü, $\varepsilon_{t}$ beyaz gürültü hata terimini ifade ederken; $\Pi$ ve $\Gamma_{\mathrm{i}}$ ise matrislerdir. Johansen eşbütünleşme testinde $\Pi$ matrisinin rankının bulunmasından hareket edilir. Rankı eşbütünleşme vektör sayısını veren $\Pi$, eşbütünleşme ilişkisine dair bilgiyi içerir. R sayıda eşbütünleşme vektörü varsa matrisin rankı da r'dir. Matrisin ankı 0 ile $\mathrm{N}$ arasında ise değişkenler vektörünün tüm bileşenleri eşbütünleşiktir ve $\mathrm{r}$ sayıda eşbütünleşme vektörü mevcuttur, eşbütünleşme vardır ve model kısıtlanmış diğer bir ifadeyle $\rho$-1 gecikmeli vektör hata düzeltme modeline dönüşür. Bu durumda $\Pi$ katsayı matrisi, $\alpha$ ve $\beta$ Nxr boyutlu matrisler olmak üzere $\Pi=\alpha \beta$ ' şeklinde gösterilebilir. $\beta$ matrisi $r$ sayıda eşbütünleşme vektörü içeren eşbütünleşme matrisidir. Eşbütünleşme vektörlerinin tahmininde Johansen'in (1988) önerdiği olabilirlik oranına dayalı iz (trace) testi ve maksimum özdeğer (maximum eigenvalue) testleri kullanılabilmektedir. Maksimum özdeğer istatistiği, eşbütünleşme vektör sayısının $r$ olduğunu ifade eden sıfır hipotezini, $r+1$ olduğunu ifade eden alternatif hipoteze karşı test eder.

Matrisinin tahmininden Gaussian hata terimleri elde etmek amaciyla uygun gecikme uzunluğunun bulunması gerekir. Uygun gecikme uzunluğun tespiti, değişkenlerin düzey değerleriyle yer aldığı bir VAR modeli tahmini ve ilgili kriterlerin dikkate alınması ile yapılır (Asteriou ve Hall, 2007: 322; Enders, 2014: 69). Johansen eşbütünleşme testinden önce, uzun ve kısa dönemli ilişkilerde yer alacak deterministik bileşenlerin bulunması için de Pantula (1989) tarafından ortaya konan ilkelere göre karar verilir. Çalışmada eşbütünleşme analizi için Johansen eşbütünleşme testi yapılmıştır.

Eşbütünleşme analizinin ilk aşamasında finansal gelişmişlik ve AR-GE harcamaları arasındaki ilişkileri araştırmak amacıyla 3 değişkenli VAR modeli kurulmuştur. VAR modeline ilişkin uygun gecikme uzunluğunun tespiti için maksimum gecikme uzunluğu, veriler yıllık olduğundan 2 olarak alınmıştır. Uygun gecikme uzunluğunun tespitinde sıkça kullanılan LR (LR test istatistiği), FPE (Son tahmin hata kriteri), AIC (Akaike bilgi kriteri), SIC (Schwarz bilgi kriteri) ve HQ (Hannan-Quinn bilgi kriteri) kriterlerine göre uygun gecikme uzunlukları aşağıdaki gibidir: 
Tablo 2. Uygun gecikme uzunluğunu gösteren kriterler

\begin{tabular}{|c|c|c|c|c|c|}
\hline $\begin{array}{c}\text { Gecikme } \\
\text { uzunluğu }\end{array}$ & LR & FPE & AIC & SIC & HQ \\
\hline 0 & NA & 0,002641 & 2,576767 & 2,724875 & 2,614016 \\
\hline 1 & $68,03975^{*}$ & 0,000163 & $-0,221664$ & $0,370768^{*}$ & $-0,072669$ \\
\hline 2 & 15,45434 & $\mathbf{0 , 0 0 0 1 4 2 *}$ & $\mathbf{- 0 , 4 0 4 9 5 1 *}$ & 0,631804 & $-0,144210^{*}$ \\
\hline
\end{tabular}

Liew’e (2004) göre gözlem sayısı 60'ın altında olan göreceli küçük veri setlerinde FPE ve AIC kriterleri daha doğru sonuçlar verdiğinden dolayı, VAR modeli için uygun gecikme uzunluğu 2 olarak seçilmiştir. Eşbütünleşme analizinin doğru sonuçlar verebilmesi için tahmin edilen VAR modelinde hata terimleri arasında otokorelasyon bulunmamalı ve hata terimlerinin varyansı sabit olmalıdır. VAR (2) modeline ilişkin serisel korelasyon LM ve White heteroskedastisite test sonuçları aşağıdaki gibidir:

Tablo 3. VAR (2) modeli için otokorelasyon ve değişen varyans testleri

\begin{tabular}{|c|c|c|c|c|}
\hline \multicolumn{3}{|c|}{ Otokorelasyon } & \multicolumn{2}{c|}{ Değișen varyans } \\
\hline $\begin{array}{c}\text { Gecikme } \\
\text { uzunluğu }\end{array}$ & LM-stat & p-değeri & Ki-kare & p-değeri \\
\hline 1 & 10,89854 & 0,2827 & 77,75871 & 0,3005 \\
\hline 2 & 7,149024 & 0,6216 & & \\
\hline 3 & 12,83368 & 0,1703 & & \\
\hline 4 & 9,761122 & 0,3702 & & \\
\hline
\end{tabular}

2 gecikmeli VAR modelinde otokorelasyon ve değișen varyansın varlığını ifade eden alternatif hipotezler $\left(\mathrm{H}_{1}\right), \% 5$ anlamlılık düzeyinde reddedildiğinden modelde otokorelasyon ve değişen varyans sorunları bulunmamaktadır. İstikrar, VAR modelinin sağlaması gereken bir diğer koşuldur. Modelin stabilitesi için ters köklere bakılmıştır.

Şekil 1. AR karakteristik polinomunun ters kökleri

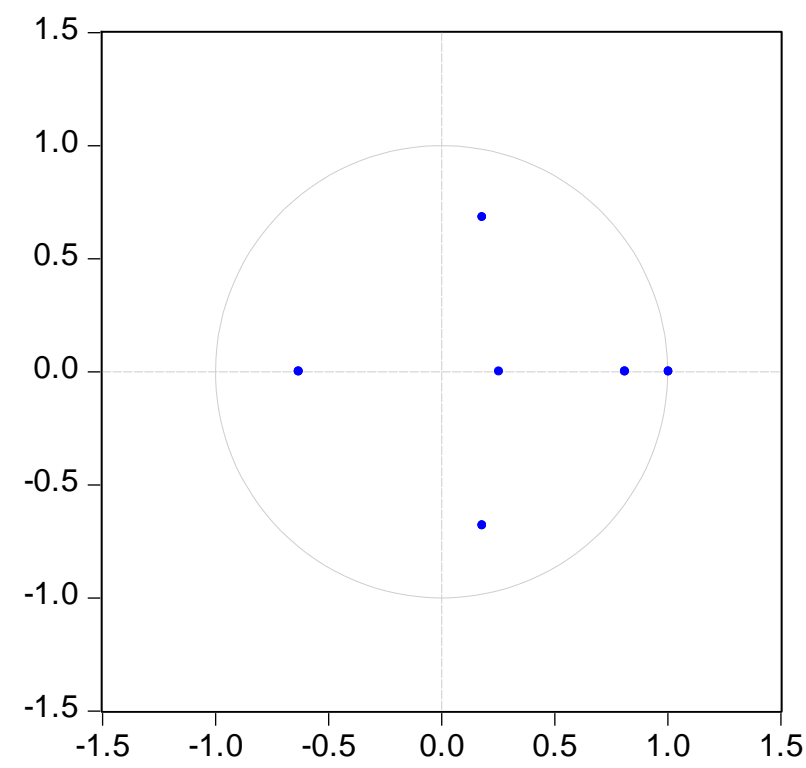


Polinomun ters köklerinin birim çember içinde yer alması, modelde istikrar sorunun bulunmadığını göstermektedir. Vektör hata düzeltme modeline ilişkin eşbütünleşme denkleminde ve VAR modelinde yer alacak deterministik bileşenlerin tespiti için ise Pantula prensibinden yararlanılmış ve eşbütünleşme denkleminde sabitin olduğu, trendin olmadığ, VAR modelinde sabit ve trendin olmadığı Model 2, \%5 anlamlılık düzeyinde uygun model olarak seçilmiştir. Model 2'nin kullanıldığı Johansen eşbütünleşme testlerinin sonuçları aşağıdaki gibidir:

Tablo 4. Johansen eşbütünleşme testi

\begin{tabular}{|c|c|c|}
\hline \multirow[b]{2}{*}{$\begin{array}{l}\text { Maksimum özdeğer istatistiği } \\
\text { (p-değeri) }\end{array}$} & Kritik değer $\% 5$ & Eşbütünleşme hipotezleri \\
\hline & Maksimum özdeğer & $\begin{array}{cc}\mathrm{H}_{0} & \mathrm{H}_{1} \\
\text { Maksimum özdeğer }\end{array}$ \\
\hline $\begin{array}{c}27,82 \\
(0,0077) \\
\end{array}$ & 22,29 & $\mathrm{r}=0 \quad \mathrm{r}=1$ \\
\hline $\begin{array}{c}4,30 \\
(0,9401)\end{array}$ & 15,89 & $\mathrm{r}<=1 \quad \mathrm{r}=2$ \\
\hline $\begin{array}{c}2,32 \\
(0,7118)\end{array}$ & 9,16 & $\mathrm{r}<=2 \quad \mathrm{r}=3$ \\
\hline
\end{tabular}

Sonuçlar, LFD1, LFD2 ve LRE değişkenleri arasında eşbütünleşme ilişkisinin olmadığını ifade eden sıfır hipotezinin \%5 anlamlılık düzeyinde reddedildiğini, 'en fazla 1 eşbütünleşme vektörü vardır' şeklinde kurulan sıfır hipotezininin reddedilemediğini ve zaman serilerinin aralarında bir eşbütünleşme vektörünün bulunduğunu göstermektedir. Buna göre uzun dönemde üç değişken arasında gerçek bir ekonomik ilişki bulunmaktadır. Eşbütünleşme denklemi, LRE bağımlı değişken olacak şekilde normalize edildiğinde, aşağıdaki gibidir:

$$
\begin{gathered}
\mathrm{LRE}=-6,364+0,677 \mathrm{LFD} 1+0,816 \mathrm{LFD} 2 \\
\text { standart hata }(0,089) \quad(0,091)
\end{gathered}
$$

Eşbütünleşme denklemi, LFD1 ve LFD2 değişkenlerinin katsayıları istatistiksel olarak anlamlı olmakla birlikte, finansal gelişmişlik ve özel sektör AR-GE harcamalarının GSYİH'ya oranı arasında uzun dönemde pozitif bir ilişkinin olduğunu göstermektedir. Uzun dönem ilişkisini gösteren regresyon sonucuna göre kredi piyasas1 ve hisse senedi gelişmişliğindeki \%1'erlik artışla birlikte AR-GE yoğunluğu sırasıyla yaklaşık \%0,7 ve \%0,8 artmaktadır. Eşbütünleşme eşitliği uzun dönemde hisse senedi piyasasının AR-GE harcamaları üzerinde kredi piyasasına göre daha fazla etkili olduğunu da göstermektedir. Eşbütünleşme analizi seriler arasında uzun dönemli ilişkinin ve nedenselliğin varlığını ortaya koymakla birlikte nedenselliğin yönü hakkında bilgi vermez. Bu nedenle nedensellik analizi için vektör hata düzeltme modelinin tahmin edilmesi gerekir. 


\subsubsection{Vektör hata düzeltme modeli (VECM) ve nedensellik testleri}

Nedensellik, Granger'ın 1969'daki çalışmasında ortaya koyduğu çerçeve ile yaygın olarak kullanılmaya başlamıştır. Granger'a göre X'in gecikmeli değerleri Y'nin değerlerinin tahmin edilmesine yardımcı oluyorsa, 'X, Y'nin Granger nedenidir' denir. Zaman serileri arasındaki nedensellik ilişkilerini inceleyen testler arasında bulunan standart Granger nedensellik testi düzeyde durağan seriler için değişkenlerin gecikmeli değerlerinin eşitliğin sağ tarafinda yer aldığı üç değişkenli VAR modelinin tahminine dayanır. Engle ve Granger'a (1987) göre zaman serileri arasında eşbütünleşme ilişkisi tespit edilirse VAR modeline dayalı Granger testinin geçerli olmayacaktır ve bu durumda seriler arasındaki nedensellik ilişkilerinin araştırılması için vektör hata düzeltme modeli (VECM) kullanılmalıdır. Aynı yazarlar, değişkenler arasında en az bir adet uzun dönemli denge ilişkisi varsa en az bir adet de uzun dönemli nedensellik ilişkisinin bulunacağını belirtmişlerdir. Kısa ve uzun dönemli nedensellik ilişkilerinin incelenmesi için $\mathrm{X}, \mathrm{Y}$ ve $\mathrm{Z}$ bağımlı değişkenlerine göre VECM kurulur. Üç değişken için vektör hata düzeltme modeli çerçevesinde aşağıdaki hata düzeltme modelleri (ECM) en küçük kareler yöntemi ile tahmin edilir (Hongyu vd., 2002: 45; Loizides ve Vamvoukas, 2005: 135; Ho vd., 2005: 252; Kang, 2015: 27-28):

$$
\begin{aligned}
& \Delta \mathrm{X}_{\mathrm{t}}=\sum_{j=1}^{m} \mathrm{a}_{\mathrm{j}} \Delta \mathrm{X}_{\mathrm{t}-\mathrm{j}}+\sum_{j=1}^{m} \mathrm{~b}_{\mathrm{j}} \Delta \mathrm{Y}_{\mathrm{t}-\mathrm{j}}+\sum_{j=1}^{m} \mathrm{c}_{\mathrm{j}} \mathrm{Z}_{\mathrm{t}-\mathrm{j}}+\alpha \mathrm{ECT}_{1, \mathrm{t}-1}+\varepsilon_{\mathrm{t}} \\
& \Delta \mathrm{Y}_{\mathrm{t}}=\sum_{j=1}^{m} \mathrm{~d}_{\mathrm{j}} \Delta \mathrm{X}_{\mathrm{t}-\mathrm{j}}+\sum_{j=1}^{m} \mathrm{e}_{\mathrm{j}} \Delta \mathrm{Y}_{\mathrm{t}-\mathrm{j}}+\sum_{j=1}^{m} \mathrm{f}_{\mathrm{j}} \mathrm{Z}_{\mathrm{t}-\mathrm{j}}+\beta \mathrm{ECT}_{2, \mathrm{t}-1}+\mu_{\mathrm{t}} \\
& \Delta \mathrm{Z}_{\mathrm{t}}=\sum_{j=1}^{m} \mathrm{~g}_{\mathrm{j}} \Delta \mathrm{X}_{\mathrm{t}-\mathrm{j}}+\sum_{j=1}^{m} \mathrm{~h}_{\mathrm{j}} \Delta \mathrm{Y}_{\mathrm{t}-\mathrm{j}}+\sum_{j=1}^{m} \mathrm{k}_{\mathrm{j}} \mathrm{Z}_{\mathrm{t}-\mathrm{j}}+\delta \mathrm{ECT}_{3, \mathrm{t}-1}+\rho_{\mathrm{t}}
\end{aligned}
$$

Hata düzeltme denklemlerindeki $\mathrm{ECT}_{1, \mathrm{t}-1}, \mathrm{ECT}_{2, \mathrm{t}-1}$ ve $\mathrm{ECT}_{3, \mathrm{t}-1}$ hata düzeltme terimleri ve $\alpha, \beta$ ve $\delta$ da hata düzeltme teriminin katsayılarıdır. $\mathrm{ECT}_{1, \mathrm{t}-1, \mathrm{ECT}_{2, \mathrm{t}-1} \text { ve }}$ $\mathrm{ECT}_{3, \mathrm{t}-1}$ sirasıyla $\mathrm{X}, \mathrm{Y}$ ve Z'nin bağımlı değişken olarak alındığı eşbütünleşme denkleminin tahmin edilmesi ile elde edilen hata teriminin 1 dönem gecikmeli değerleridir. Hata teriminin katsayısı belirli bir anlamlılık düzeyinde anlamlı ve negatif ise 'bağımsız değişkenler uzun dönemde bağımlı değişkenin Granger nedenidir' şeklinde yorumlanırken, bağımsız değişkenin gecikmeli değerlerinin katsayılarının bir bütün olarak anlamlı olması ise 'bağımsız değişken kısa dönemde bağımlı değişkenin Granger nedenidir' şeklinde açıklanır. 1 gecikmeli VECM'ye dayalı uzun dönemli ve kısa dönemli Granger nedensellik test sonuçları aşağıdaki gibidir: 
Tablo 5. VECM'ye dayalı Granger nedensellik testleri

\begin{tabular}{|c|c|c|c|c|c|}
\hline Değişkenler & $\begin{array}{c}\Delta \mathrm{LRE} \\
\text { (Bağımsız } \\
\text { değ.) } \\
\text { F-istatistiği } \\
\text { (p-değeri) }\end{array}$ & $\begin{array}{c}\Delta \text { LFD1 } \\
\text { (Bağımsız } \\
\text { değ.) } \\
\text { F-istatistiği } \\
\text { (p-değeri) }\end{array}$ & $\begin{array}{c}\Delta \text { LFD2 } \\
\text { (Bağımsiz } \\
\text { değ.) } \\
\text { F-istatistiği } \\
\text { (p-değeri) }\end{array}$ & $\begin{array}{c}\mathrm{ECT}_{\mathrm{t}-1}{ }^{\prime} \mathrm{nin} \\
\text { katsayisi } \\
\text { (t-istatistiği) } \\
\text { (p-değeri) }\end{array}$ & $\begin{array}{l}\text { Varsayım } \\
\text { testleri } \\
\text { (p-değeri) }\end{array}$ \\
\hline $\begin{array}{c}\Delta L R E \\
\text { (Bağımlı } \\
\text { değ.) }\end{array}$ & -- & $\begin{array}{c}\mathbf{0 , 4 2 5} \\
(\mathbf{0 , 5 1 4 1 )}\end{array}$ & $\begin{array}{c}\mathbf{6 , 0 1 7} \\
(\mathbf{0 , 0 1 4 2 )}\end{array}$ & $\begin{array}{c}-0,409(-2,093) \\
(0,0500)\end{array}$ & $\begin{array}{c}\text { LM }(0,1416) \\
\text { ARCH } \\
(0,1211)\end{array}$ \\
\hline $\begin{array}{c}\Delta \text { LFD1 } \\
\text { (Bağımlı } \\
\text { değ.) }\end{array}$ & $\begin{array}{c}0,011 \\
(0,9132)\end{array}$ & -- & $\begin{array}{c}0,019 \\
(0,8890)\end{array}$ & $\begin{array}{c}-0,016(-0,153) \\
(0,8799)\end{array}$ & $\begin{array}{c}\text { LM }(1,0000) \\
\text { ARCH } \\
(0,6334) \\
\end{array}$ \\
\hline $\begin{array}{c}\Delta \text { LFD2 } \\
\text { (Bağıml1 } \\
\text { değ.) }\end{array}$ & $\begin{array}{c}4,050 \\
(0,0442)\end{array}$ & $\begin{array}{c}1,485 \\
(0,2230)\end{array}$ & -- & $\begin{array}{c}-0,077(-2,100) \\
(0,0493)\end{array}$ & $\begin{array}{c}\text { LM }(1,0000) \\
\text { ARCH } \\
(0,5056)\end{array}$ \\
\hline
\end{tabular}

LRE'nin bağımlı değişken olarak yer aldığı modelde hata düzeltme teriminin $\left(\mathrm{ECT}_{\mathrm{t}-1}\right)$ katsayısı negatiftir ve katsayının anlamlı olmadığını ifade eden sıfır hipotezi $\% 5$ anlamlılık düzeyinde reddedilirken, katsayının anlamlı olması LFD1 ve LFD2'den LRE'ye doğru uzun dönemde nedensellik olduğunu göstermektedir. Diğer bir ifadeyle finansal gelişmişlik uzun dönemde AR-GE yoğunluğunun Granger nedenidir. LFD2 değişkeninin gecikmeli değerlerinin katsayılarının bir bütün olarak anlamlı olması ise k1sa dönemde LFD2'den LRE'ye doğru nedenselliğin varlığını ifade etmektedir. VECM'ye göre bağımlı değişken LRE'nin kısa ve uzun dönem değerleri arasındaki sapmaların yaklaşık \%40'1 her yıl düzeltilmekte ve sistem yaklaşık 2,5 senede dengeye gelmektedir. Diğer taraftan model tahmin sonuçlarına göre $\% 5$ anlamlılık düzeyinde LFD1'den LRE'ye doğru kısa dönemde nedensellik bulunmamaktadır. LFD2'nin bağımlı değişken olarak bulunduğu modelin tahmin sonuçları da LRE ve LFD1'den LFD2'ye doğru uzun dönemde, LRE'den LFD2'ye doğru kısa dönemde nedenselliğin varlığını işaret etmektedir. Modellerin tahmin sonuçları, kısa dönemde kredi piyasası gelişmişliği ve hisse senedi piyasası gelişmişliği arasında nedensellik ilişkisinin bulunmadığını da göstermektedir. Tahmin edilen modellerde Breusch-Godfrey serisel korelasyon $\mathrm{LM}$ ve $\mathrm{ARCH}$ heteroskedastisite testlerine göre $\% 5$ anlamlılık düzeyinde otokorelasyon ve değişen varyans sorunları bulunmamaktadır.

VECM'ye dayalı Granger nedensellik test sonuçları; ülkemizde özel sektör ARGE yoğunluğunun finansal gelişmişliğe uzun dönemde, hisse senedi piyasası gelişmişliğine de kısa dönemde bağımlı olduğunu göstermektedir. Çalışmada ulaşılan finansal gelişmişlik ve AR-GE yoğunluğu arasındaki uzun dönemli pozitif ilişki de dikkate alındığında, model tahmin sonuçlarının; finansal gelişmişlik ve AR-GE harcamaları ilişkisini konu alan özellikle de hisse senedi piyasasının AR-GE harcamaları üzerinde daha fazla pozitif etkiye sahip olduğuna yoğunlaşan teorileri desteklediği söylenebilir. 
VAR/VECM modelinin tahminiyle elde edilen katsayıların yorumlanmasının güç olmasına ek olarak VECM modeline dayalı kısa dönemli nedensellik testleri, sistemdeki değişkenlerin gecikmeli değerlerinin bir bütün olarak anlamlllı̆̆ına odaklanırken diğer bir ifadeyle bağımsız değişkenin bağımlı değişkenin gelecekteki değerlerine etkisini incelerken, bir değişkende ortaya çıkan değiş̧imin diğer değişkenler üzerindeki kısa dönemde etkisinin pozitif mi ya da negatif mi olduğu, bu etkinin ne kadar sürdüğü ve sistem çerçevesinde değişkende ortaya çıkan değişimin kaynaklarının ne olduğu hakkında fikir vermez. Bu noktada değişkenler arasındaki dinamik ilişkilerin analizi için VECM modelinin tahminine dayanan etki-tepki analizine ve varyans ayrıştırmasına ihtiyaç duyulur (Brooks, 2008: 298-300).

\subsubsection{Etki-Tepki Analizi}

Etki-tepki analizi, VAR/VECM modeli çerçevesinde tahmin edilen ve belirli bir zamanda ortaya çıkan şokun değişkenlerin gelecekteki değerleri üzerindeki etkisini dinamik bir sistem içerisinde ölçen etki-tepki fonksiyonunun tahmini ile yapilır. Etkitepki analizinde VECM sistemindeki bağımlı değişkenlerin, ortaya çıkan şoklar karşısında değişimleri takip edilir (Pesaran ve Shin, 1998: 3; Gujarati, 2003: 853-854). Analizde VECM modelindeki her bir eşitlikteki bağımlı değişken için hata terimine uygulanan bir birim şok (etki) için VECM sistemindeki içsel değişkenlerin gelecekteki dönemlerde vermeleri beklenen tepkiler analiz edilir (Enders, 2014: 295-297). Çalışmanın asıl konusu finansal gelişmişliğin AR-GE yoğunluğuna etkisi olduğundan, Pesaran ve Shin'in (1998) önerdiği değişkenlerin sıralamasından etkilenmeyen genelleştirilmiş ve LRE'nin bağımlı değişken olarak yer aldığı etki-tepki fonksiyonlarının tahmin sonuçları aşağıdaki gibidir²:

Grafik 4. Etki-tepki analizi

Accumulated Response to Generalized One S.D. Innovations

Accumulated Response of LRE to LFD1

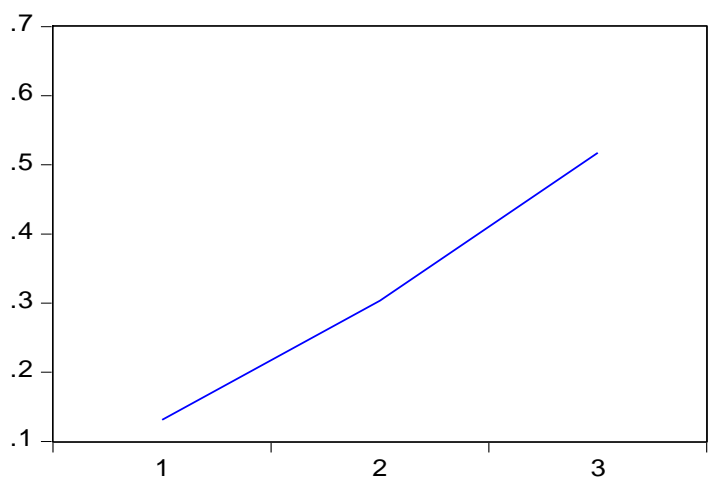

Accumulated Response of LRE to LFD2

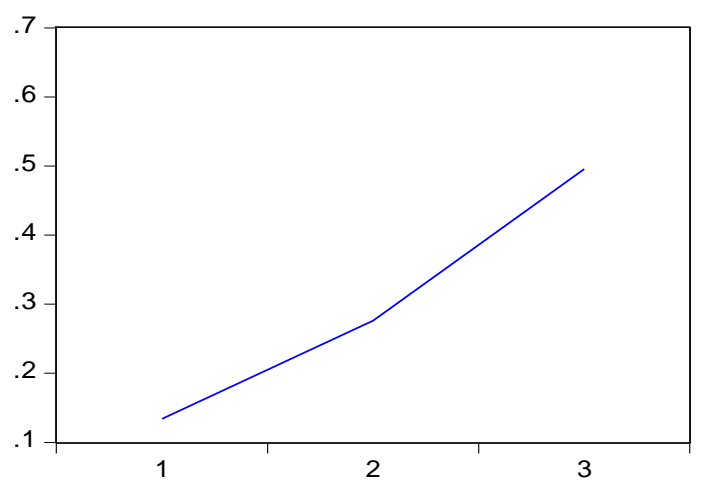

\footnotetext{
${ }^{2}$ Verilerin yıllık olmasına bağlı olarak şok karşısından tepkilerin uzun yıllar sürmeyeceği gerçeğinden hareketle etki-tepki fonksiyonları sonuçları 3 yıllık periyod için verilmiştir.
} 
Grafiklerdeki çizgiler, modelin hata teriminde ortaya çıkan 1 standart sapmalık şok karşısında içsel değişkenlerin verdiği tepkileri ifade etmekteyken grafiklerdeki yatay eksen tepkinin süresini, dikey eksen ise tepkinin boyutunu göstermektedir. Buna göre hisse senedi ve kredi piyasasında meydana gelen 1 standart sapmalık pozitif şoklar AR-GE yoğunluğunu ilk 3 yıl kümülatif olarak artırmaktadır. Analiz sonuçları, finansal gelişmişteki artışın kısa dönemde AR-GE harcamalarının GSYIH'ya oranını da artırdığını ve aralarındaki teorik pozitif ilişkinin varlığını teyit etmektedir.

\subsubsection{Varyans Ayrıştırması}

Etki-tepki analizi değişkenlerdeki değişimin işareti, süresi ve büyüklüğü ile ilgili bilgi verirken, varyans ayrıştırması ise değişkenlerin değişimi hangi oranlarda etkilediği hakkında bilgi sağlar. Varyans ayrıştırması, bağımlı değişkenlerdeki değişimlerin ne kadarının kendi şoklarından ne kadarının da diğer değişkenlerin şoklarından kaynaklandığını ortaya koyar. Bir değiş̧kende ortaya çıkan şok, doğrudan bu değişkeni etkilemekle beraber VAR/VECM sisteminin dinamik yapısıyla birlikte diğer değişkenleri de etkileyecektir. Varyans ayrıştırması ile ilgili değişkenin tahmin hata varyansının, kendi şokları ve diğer değişkenlerin şokları tarafından açıklanma oranı belirlenir (Brooks, 2008: 300-301). Cholesky ayrıştırma yönteminin kullanıldığı, hata terimi aralıklarının 100 yinelemeli Monte-Carlo simülasyonu ile hesaplandığı ve Boubtane, Coulibaly ve Rault'a (2012) göre en dışsal değiş̧kenin ilk sırada yer aldığı LRE değiş̧kenine ait 3 yıllık varyans ayrıştırma tahminleri aşağıdaki gibidir:

Tablo 6. Varyans ayrıştırması

\begin{tabular}{|c|c|c|c|c|}
\hline \multicolumn{5}{|c|}{ LRE Varyans Ayrıştırmas1 } \\
\hline Dönem (Y1l) & S.E. & LRE & LFD1 & LFD2 \\
\hline 1 & 0,194285 & 27,36392 & 24,92548 & 47,71060 \\
\hline 2 & 0,284706 & 18,03747 & 34,87604 & 47,08649 \\
\hline 3 & 0,394197 & 10,25588 & 34,20711 & 55,53701 \\
\hline
\end{tabular}

Üç değişkenli VECM sisteminde hisse senedi piyasası gelişmişliği, kısa dönemde AR-GE yoğunluğunun tahmin hata varyansının yaklaşı \%56'sını açıklamaktadır, diğer bir ifadeyle AR-GE yoğunluğundaki değişimlerin \%56'sı hisse senedi piyasası kaynaklıdır. Hisse senedi piyasasında ortaya çıkan bugünkü değişimler AR-GE yoğunluğunun gelecekteki değerlerini çok yüksek oranda etkilemektedir. 3. yılda AR-GE yoğunluğundaki değişimlerin \%10'u kendi şokları, \%56'sı hisse senedi piyasası şokları, \% 34'ü de kredi piyasası şokları tarafından açıklanmaktadır. Varyans ayrıştırma sonuçları finansal gelişmişliğin özel sektör AR-GE yoğunluğundaki değişimin önemli kaynakları arasında yer aldığını göstermektedir. 


\section{SONUÇ}

İnovasyon faaliyetleri ülke ekonomileri ve işletmeler açısından giderek daha önemli hale gelmekte ve küresel piyasalardaki yüksek rekabet uzun dönemde verimliliklerini, kârlarını ve pazar paylarını korumayı/artırmayı amaçlayan özel sektör işletmelerini AR-GE yatırımlarına daha fazla kaynak ayırmaya zorlamaktadır. Fakat bu yatırımların kendine özgü taşıdığı yüksek riskler, harcamaların finanse edilme imkânlarını daraltmakta ve AR-GE harcamalarını finansal sistemin gelişmişliğine bağımlı hale getirmektedir. $\mathrm{Bu}$ nedenle özel sektör AR-GE yoğunluğu ve finansal gelişmişlik arasındaki yakın ilişkinin ayrıntılı şekilde analiz edilmesi gereği ortaya çıkmaktadır. İki değişken arasındaki dinamik ilişkilerin analiz edilmesi, inovasyonların asıl kaynağ1 konumundaki özel sektör işletmelerine yönelik uygulanacak finansman politikaları ve ulusal düzeyde ekonomi açısından önem arz eden inovasyon stratejileri açısından da önem taşımaktadır. Bu bağlamda çalışmada, hisse senedi piyasası ve kredi piyasası olmak üzere iki alt gösterge ile temsil edilen finansal gelişmişlik ve özel sektör AR-GE yoğunluğu arasındaki ilişkiler, 1990-2014 döneminde y1llık veriler kullanılarak eşbütünleşme, nedensellik, etki-tepki analizleri ve varyans ayrıştırması ile incelenmiştir. Eşbütünleşme analizi; finansal gelişmişlik ve özel sektör AR-GE harcamalarının GSYİH'ya oranı arasında uzun dönemde pozitif bir eşbütünleşik ilişkinin varlığını ve hisse senedi piyasasının AR-GE harcamaları üzerinde kredi piyasasına göre daha fazla etkili olduğunu da ortaya koymaktadır. Nedensellik analizi, finansal gelişmişlikten ARGE yoğunluğuna doğru uzun dönemde, hisse senedi piyasasından AR-GE yoğunluğuna doğru kısa dönemde nedensellik olduğunu göstermektedir. Eşbütünleşme ve nedensellik analizi sonuçları; kredi piyasasının büyümesinin özel sektör işletmelerinin AR-GE harcamalarını artırabileceğini öne süren Kerr ve Nanda'nın (2015), hisse senedi piyasasının gelişmesinin işletmeleri AR-GE yatırımlarına yönlendirebileceğini savunan Brown, Martinsson ve Petersen'in (2012) ve özel sektör AR-GE yatırımları açısından hisse senedi piyasasının kredi piyasasına göre daha etkili olabileceğini savunan Brown, Fazzari ve Petersen'in (2009) ve Hall ve Lerner'in (2010) görüşlerini desteklemektedir. Etki-tepki analiz sonuçları da finansal gelişmişlikteki artışın uzun dönemde olduğu gibi kısa dönemde de özel sektör AR-GE yoğunluğunu artırdığını ortaya koymakta ve aralarındaki teorik pozitif ilişkiyi desteklemektedir. Varyans ayrıştırmasına göre ise hisse senedi piyasası, AR-GE yoğunluğundaki kısa dönemli değişimleri kredi piyasasıyla karşılaştırıldığında daha yüksek bir oranla açıklamaktadır.

Çalışmada yapılan analiz sonuçları, finansal gelişmişliği artıracak politikaların özel sektör AR-GE yoğunluğunu da artıracağını göstermektedir. Ülkemizde AR-GE faaliyetlerinde bulunan işletmelerin finansman olanaklarının artırılması ekonomik büyümenin en önemli kaynaklarından biri olarak kabul edilen inovasyonları da artırabilecektir. $\mathrm{Bu}$ tür işletmelere yönelik sağlanacak daha cazip kredi faiz oranı indirimleriyle birlikte özellikle halka açılarak hisse senedi piyasasına girmek isteyen 
işletmelere yönelik uygulanacak daha geniş kapsamlı teşvik ve muafiyetler; ülkemizde AR-GE faaliyetlerinde karşılaşılan finansman sorunlarını azaltabilecek ve daha fazla işletmenin AR-GE faaliyetlerinde bulunmasını sağlayabilecektir. Sonuçta özel sektörün AR-GE faaliyetlerine daha çok yoğunlaşması, ülkemizdeki ekonomik büyüme ve refah artı̧ına ciddi katkılarda bulunabilecektir. Uygulanacak bu tür politikaların işlerliği, ulusal düzeyde etkin bir inovasyon sisteminin varlığıyla birlikte daha da artabilecektir.

\section{KAYNAKLAR}

Aghion, Philippe - Howitt, Peter (1992), "A Model of Growth Through Creative Destruction”, Econometrica, 60, 2, pp. 323-351.

Akınc1, Gönül Yüce - Akıncı, Merter - Yılmaz, Ömer (2014), "Finansal Kalkınma Sürecinin AR-GE Harcamaları Üzerindeki Etkisi: Schumpeter Haklı mıdı?", Maliye Dergisi, 166, Ocak-Haziran 2014, ss. 56-74.

Allen, Franklin - Carletti, Elena - Qian, Jun - Valenzuela, Patricio (2012), "Financial Intermediation, Markets, and Alternative Financial Sectors", http://apps.eui.eu/Personal/Carletti/Handbook_ACQV_25March2012.pdf (21.10.2016).

Allen, Franklin - Gale, Douglas (2001), “Comparative Financial Systems: A Survey (Financial Institutions Center at The Wharton School, Working Paper No: 0115)", https://core.ac.uk/download/pdf/6649943.pdf (20.10.2016).

Asteriou, Dimitrios - Hall, Stephen G. (2007), Applied Econometrics, Palgrave Macmillan, New York.

Atkinson, Robert - Wial, Howard (2008), "Boosting Productivity, Innovation and Growth Through a National Innovation Foundation", http://www.brookings.edu/ /media/files/rc/reports/2008/04_federal_role_atkinso n_wial/nif\%20report.pdf (2.11.2016).

Ayaydın, Hasan - Karaaslan, İbrahim (2014), "The Effects of Research and Development Investments on Firms' Financial Performance: Evidence from Manufacturing Firms in Turkey", Bilgi Ekonomisi ve Yönetimi Dergisi, IX, II, ss. 43-59.

Berglund, Anders (2007), Assesing the Innovation Process of SMEs, Lulea University of Technology, Lulea.

Boubtane, Ekrame - Coulibaly, Dramane - Rault, Christophe (2012), “Immigration, Growth and Unemployment: Panel VAR Evidence from OECD Countries (IZA Discussion Paper No: 6966)", http://ftp.iza.org/dp6966.pdf (21.10.2016).

Brooks, Chris (2008), Introductory Econometrics for Finance, Cambridge University Press, New York. 
Brown, James R. - Fazzari, Steven M. - Petersen, Bruce C. (2009), "Financing Innovation and Growth: Cash Flow, External Equity, and the 1990s R\&D Boom', The Journal of Finance, 64, 1, pp. 151-185.

Brown, James R. - Martinsson, Gustav - Petersen, Bruce C. (2012), “Do Financing Constraints Matter for R\&D?', European Economic Review, 56, 8, pp. 15121529.

Elg, Lennart (2014), “Innovations and New Technology (VINNOVA Analysis 2015.5)', $\quad$ http://www.vinnova.se/en/Publications-andevents/Publications/Products/Innovations-and-new-technology/ (28.10.2016).

Enders, Walter (2014), Applied Econometric Time Series, John Wiley\&Sons, New Jersey.

Engle, Robert F. - Granger, Clive William John (1987), "Co-integration and Error Correction: Representation, Estimation and Testing', Econometrica, 55, 2, pp. 251-276.

European Commission (2000), "Innovation Policy in a Knowledge-Based Economy", https://cordis.europa.eu/innovationpolicy/studies/pdf/studies_knowledge_based_economy.pdf (19.10.2016).

European Commission (2004), "Innovation Management and the Knowledge-Driven Economy', https://cordis.europa.eu/innovationpolicy/studies/pdf/studies_innovation_management_final_report.pdf (14.11.2016).

Fazzari, Steven M. - Hubbard, R. Glenn - Petersen, Bruce C.(1988), "Financing Constraints and Corporate Investment', Brooking Papers on Economic Activity, 1988, 1, pp. 141-195.

Fitzgerald, Valpy (2006), “Financial Development and Economic Growth: A Critical View, Background Paper for World Economic and Social Survey 2006', http://www.un.org/en/development/desa/policy/wess/wess_bg_papers/bp_wess2 006_fitzgerald.pdf (7.11.2016).

Granger, Clive William John - Newbold, Paul (1974), "Spurious Regression in Econometrics", Journal of Econometrics, 2, 1974, pp. 111-120.

Granger, Clive William John (1981), “Some Properties of Time Series Data and Their Use in Econometric Model Specification', Journal of Econometrics, 16, 1, pp. 121-130.

Greene, William H. (2003), Econometric Analysis, Pearson Education, New Jersey.

Greenhalgh, Christine - Rogers, Mark (2010), Innovation, Intellectual Property and Economic Growth, Princeton University Press, New Jersey. 
Grossman, Gene M. - Helpman, Elhanan (1991), “Trade, Knowledge Spillovers, and Growth', European Economic Review, 35, 3, pp. 517-526.

Gujarati, Damodar N. (2003), Basic Econometrics, McGraw-Hill, New York.

Hall, Bronwyn H. - Lerner, Josh (2010), “'The Financing of R\&D and Innovation', B. H. Hall and N. Rosenberg (eds.), Handbook of the Economics of Innovation, Elsevier, Amsterdam, pp. 609-639.

Hall, Bronwyn H. - Lotti, Francesca - Mairesse, Jacques (2012), “Evidence on the Impact of R\&D and ICT Investment on Innovation and Productivity in Italian Firms", Economics of Innovation and New Technology, 22, 3, pp. 300-328.

Hall, Bronwyn H. (1992), "Investment and Research and Development at the Firm Level: Does the Source of Financing Matter? (NBER Working Paper No. 4096)', http://www.nber.org/papers/w4096 (9.11.2016).

Hall, Bronwyn H. (2002), “The Financing of Research and Development', Oxford Review of Economic Policy, 18, 1, pp. 35-51.

Hall, Bronwyn H. (2006), "Research and Development (Contribution to the International Ency. of Social Sciences)", https://eml.berkeley.edu/ bhhall/papers/BHH06_IESS_R\&D.pdf (29.9.2016).

Hansen, Bruce E. (2016), "Econometrics (University of Wisconsin Department of Economics Manuscript)", http://www.ssc.wisc.edu/ bhansen/econometrics/Econometrics.pdf (7.11.2016).

Helhel, Yeşim (2016), “E-7 Ülkelerinde Finansal Gelişmenin Ar-Ge Faaliyetleri Üzerindeki Etkisi”, Journal of Business Research Turk, 8, 1, ss. 500-517.

Himmelberg, Charles P. - Petersen, Bruce (1994), “R\&D and Internal Finance: A Panel Study of Small Firms in High-Tech Industries', The Review of Economics and Statistics", 76, 1, pp. 38-51.

Ho, Lok Sang - Wei, Xiangdong - Wong, Wai Chung (2005), "The Effect of Outward Processing Trade on Wage Inequality: The Hong Kong Case', Journal of International Economics, 67, 2005, pp. 241-257.

Hongyu, Liu - Park, Yun W. - Siqi, Zheng (2002), “'The Interaction between Housing Investment and Economic Growth in China', International Real Estate Review, 5,1 , pp. 40-60.

Houghton, John - Sheehan, Peter (2000), "A Primer on the Knowledge Economy (CSES Working Paper No: http://www.business.vu.edu.au/cses/documents/working_papers/cses/wp18_200 0_cses.pdf (24.10.2016).

Johansen, Soren - Juselius, Katarina (1990), "Maximum Likelihood Estimation and Inference on Cointegration-With Applications to the Demand for Money", Oxford Bulletin of Economics and Statistics, 52, 2, pp. 169-210. 
Johansen, Soren (1988), “Statistical Analysis of Cointegration Vectors', Journal of Economic Dynamics and Control, 12, 1988, pp. 231-254.

Johansen, Soren (1991), "Estimation and Hypothesis Testing of Cointegration Vectors in Gaussian Vector Autoregressive Models', Econometrica, 59, 6, pp. 15511580 .

Kang, Jong Woo (2015), "Interrelation Between Growth and Inequality (ADB Economics Working Paper Series https://www.adb.org/sites/default/files/publication/173116/ewp-447.pdf (21.10.2016).

Kerr, William R. - Nanda, Ramana (2015), “Financing Innovation', Annual Review of Financial Economics, 7, 1, pp. 445-462.

Khan, Jangraiz (2015), “The Role of Research and Development in Economic Growth: A Review', Journal of Economics Bibliography, 2, 3, pp. 128-133.

Levine, Ross (1997), "Financial Development and Economic Growth: Views and Agenda', Journal of Economic Literature, XXXV, 1997, pp. 688-726.

Levine, Ross (2005), "Finance and Growth: Theory and Evidence', Philippe Aghion and Steven Durlauf (Ed.), Handbook of Economic Growth, Elsevier, pp. 865934.

Liew, Venus Khim-Shen (2004), "Which Lag Length Selection Criteria Should We Employ?', Economics Bulletin, 3, 33, pp. 1-9.

Loizides, John - Vamvoukas, George (2005). “Government Expenditure and Economic Growth: Evidence from Trivariate Causality Testing', Journal of Applied Economics, VIII, 1, pp. 125-152.

Lucas, Robert Emerson (1988), “On The Mechanics of Economic Development", Journal of Monetary Economics, 22, 1988, pp. 3-42.

Lundvall, Bengt-Ake (2004), "National Innovation Systems-Analytical Concept and Development Tool (Paper to be presented at the DRUID Tenth Anniversary Summer Conference)", http://www.druid.dk/conferences/Summer2005/Papers/Lundvall.pdf (29.10.2016).

Maddala, G.S. (1992), Introduction to Econometrics, Macmillan Publishing Company, New York.

Maskus, Keith E. - Neumann, Rebecca - Seidel, Tobias (2010), “'How National and International Financial Development Affect Industrial R\&D (CESifo Working Paper Series No: 3480)', http://spot.colorado.edu/ maskus/papers/revision_EER_final_12-2010.pdf (16.11.2016). 
Merton, Robert C. - Bodie, Zvi (1995), "A Conceptual Framework for Analyzing the Financial Environment.", D. B. Crane, K. A. Froot, Scott P. Mason, André Perold, R. C. Merton, Z. Bodie, E. R. Sirri and P. Tufano (Ed.), The Global Financial System: A Functional Perspective, Harvard Business School Press, Boston, pp. 3-31.

Pantula, Sastry G. (1989), “Testing for Unit Roots in Time Series Data”, Econometric Theory, 5, 2, pp. 256-271.

Pesaran, H.Hashem - Shin, Yongcheol (1998), “Generalized Impulse Response Analysis in Linear Multivariate Models', Economic Letters, 58, 1, pp. 17-29.

Pienknagura, Samuel (2010), "Financial Development, R\&D and Growth (MIT Job Market Paper)', http://economics.mit.edu/files/6237 (4.11.2016).

Powell, Walter W. - Snellman, Kaisa (2004), “The Knowledge Economy”, Annual Review of Sociology, 2004, 30, pp. 199-220.

Rajan, Raghuram G. - Zingales, Luigi (2003), "The Great Reversals: The Politics of Financial Development in the Twentieth Century', Journal of Financial Economics, 69, 2003, pp. 5-50.

Romer, Paul Michael (1986), “Increasing Returns and Long-Run Growth”, The Journal of Political Economy, 94, 5, pp. 1002-1037.

Romer, Paul Michael (1990), “Endogenous Technological Change’, The Journal of Political Economy, 98, 5, pp. 71-102.

Schumpeter, Joseph Alois (1934), The Theory of Economic Development: An Inquiry into Profits, Capital, Credit, Interest and the Business Cycle, Oxford University Press, Oxford.

Stiglitz, Joseph (1998), “The Role of Financial System in Development (Presentation at the Fourth Annual Bank Conference on Development in Latin America and the Caribbean)', http://citeseerx.ist.psu.edu/viewdoc/download?doi=10.1.1.475.9471\&rep=rep1\& type $=$ pdf (2.11.2016).

U.S. Department Of Commerce (2012), “The Competitiveness and Innovative Capacity of United States", http://www.commerce.gov/sites/default/files/documents/2012/january/competes _010511_0.pdf (9.11.2016).

U.S. National Science Board (2012), "A Companion to Science and Engineering Indicators", https://www.nsf.gov/statistics/digest12/nsb1202.pdf (17.10.2016).

Ülkü, Hülya (2004), “R\&D, Innovation, and Economic Growth: An Empirical Analysis (IMF Working Paper No: 185)', https://www.imf.org/external/pubs/ft/wp/2004/wp04185.pdf (14.10.2016).

Wang, Peijie (2009), Financial Econometrics, Routledge, New York. 
Wooldridge, Jeffrey M. (2012), Introductory Econometrics: A Modern Approach, Cengage Learning, Ohio.

databank.worldbank.org

tuik.gov.tr 